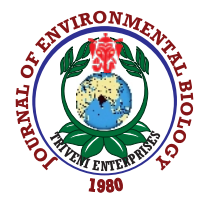

\title{
Abundance of anuran parasites and pesticide pollution from lowland and highland golf courses
}

\author{
H.K. Agustar ${ }^{1 *}$, K.M. Jansar ${ }^{1}$, A.H. Ali ${ }^{2}$ and N.F.A. Ghani ${ }^{1}$ \\ 'Department of Earth Sciences and Environment, Faculty of Science and Technology, Universiti Kebangsaan Malaysia, Bangi, 43600, Malaysia \\ ${ }^{2}$ Department of Chemical Sciences, Faculty of Science and Technology, Universiti Kebangsaan Malaysia, Bangi, 43600, Malaysia \\ *Corresponding Author Email : hani_ag@ukm.edu.my
}

\section{Abstract}

Aim: This study aimed to determine the pesticide pollution and prevalence of protozoa in anurans from lowland and highland golf courses in Malaysia and to observe the relationship between environmental factors (water quality index and pollutants) and the presence of protozoa in anurans.

Methodology: Water quality index and pesticide levels (metsulfuron methyl) were measured at three locations, i.e. Jeriau river, Fraser's hill golf course in Pahang, and UKM Danau golf club in Selangor. Microscopy techniques were used to identify and examine the prevalence of protozoa and haemoparasites in anuran organs (stomach, kidney, liver, intestine, rectum, and blood).

Results: A total of 140 anurans were collected from the study areas. Jeriau river had the highest water quality compared to Fraser's hill golf course and UKM Danau golf club. Metsulfuron methyl concentrations at all three locations were under permissible level $\left(0.001-0.01 \mathrm{mgl}^{-1}\right)$. Approximately, $30 \%$ of the anurans were infected with $\geq 1$ protozoa, of which $22.14 \%$ were from phylum Opalinata and $10.71 \%$ were from phylum Ciliophora (Nyctotherus cordiformis). Approximately $44.44 \%$ of the anurans were infected with $\geq 1$ groups of haemoparasites, which included Trypanosoma, Haemogregarina, Lankesterella, Aegyptianella and Microfilaria.

Interpretation: No significant relationship was found between the environmental parameters and the abundance of protozoa and haemoparasites in anurans from three locations, indicating that the prevalence of protozoa and haemoparasites in anurans is not influenced by environmental factors.

Key words: Anurans, Haemoparasites, Metsulfuron methyl,Protozoa, Water quality index

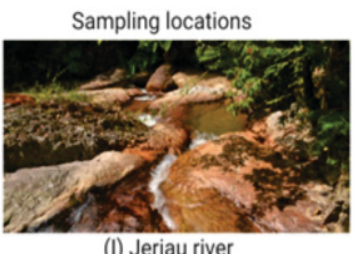

(I) Jeriau river

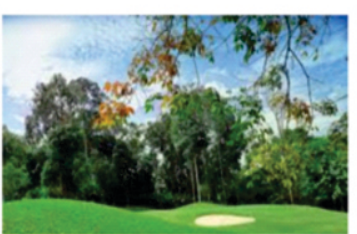

(II) UKM Danau golf club

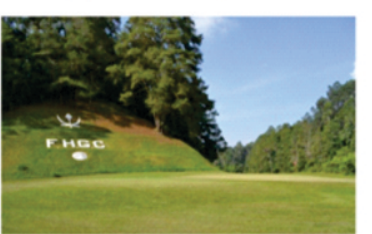

(III) Fraser's hill golf course

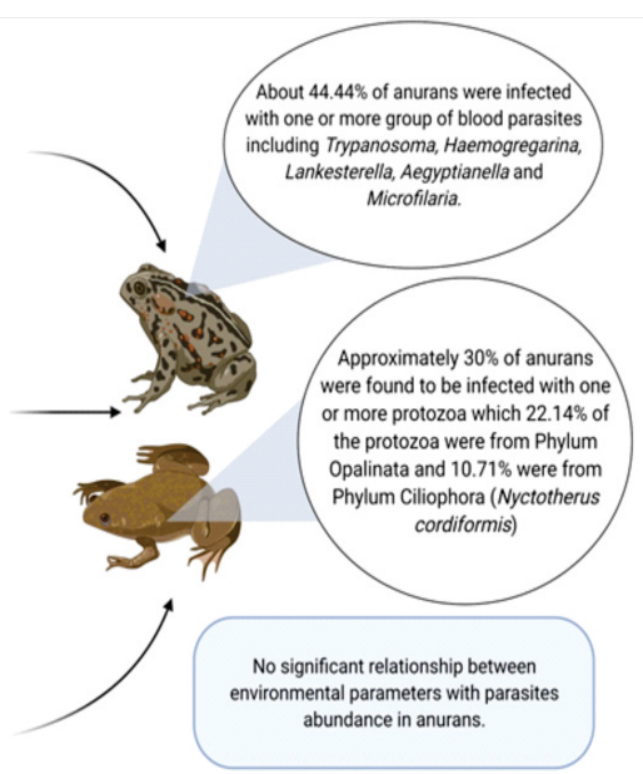

No signicant relationship between abundance in anurans.

How to cite : Agustar, H.K., K.M. Jansar, A.H. Ali and N.F.A. Ghani: Abundance of anuran parasites and pesticide pollution from lowland and highland golf courses. J. Environ. Biol., 42, 789-797 (2021). 


\section{Introduction}

The amphibian population is important in the ecosystem to maintain a stable environment. Amphibians like frogs control the insect population and are indicators of quality of the surrounding environment (Bernardo-Cravo et al., 2020; Rahman and Shakinah, 2015). Amphibians are sensitive to environmental changes in both terrestrial and aquatic habitats because they have highly semi-permeable skins and different life-cycle stages (Alford and Richards, 1999). If there are many frogs in an area, it shows a healthy environment which a frog die-off indicates a problem with the water, air or soil in their habitat. Unfortunately, the population of frog is declining at a rapid rate throughout the world (Ceballos et al., 2017; Collins and Storfer, 2003). About $40 \%$ of global amphibian populations are declining due to dwindling habitats and a rise in infectious diseases. Several factors have contributed to the rapid decline in the frog population, including diseases caused by pesticide pollution, parasites and habitat loss (Blaustein et al., 2018; Hayes et al., 2010). Pesticides exposure might weaken the immune system (Brown et al., 2021; Rohr et al., 2008) and cause limb malformations in frogs (Kiesecker, 2002). According to Sparling and Fellars (2009), exposure to chlorpyrifos and endosulfan poses a serious risk to amphibians in the Sierra Nevada mountains, as these insecticides affect acetylcholinesterase activity in amphibians. However, Bradford et al. (2011) did not support the hypothesis that pesticides have contributed to the population decline of Rana muscosa and $R$. sierrae in the Sierra Nevada mountains. Besides pesticide contamination, pathogenic parasites can also affect the anuran health state and cause mortality (Hua et al., 2017). Frogs are known as hosts to different types of protozoa, such as blood parasites. Research in Malaysia related to blood parasites in frogs is scanty, and none of the studies have shown correlation between pesticide usage with the abundance of blood parasites.

Metsulfuron methyl decreases acetylcholinesterase activity (Pretto et al., 2011) and shows similar effect as insecticides (chlorpyrifos and endosulfan) (Sparling and Fellers, 2009). Acetylcholinesterase activity in brain and white muscle of teleost fish decreased significantly $(p<0.05)$ after exposure to commercial formulations containing metsulfuron methyl when compared to control values (Pretto et al., 2011). However, pesticide usage has increased in agriculture, and this may affect the persistence and health of amphibian population. Amphibians found in agricultural areas may be exposed to toxic effects of pesticides and the pesticides used not only affect the frog population, but also affect the parasites in the frogs (Bruhl et al., 2013). Bruhl et al. (2013) studied the effects of pesticide products on juvenile European common frogs and found that the mortality of juvenile frogs decreased by $40 \%$ after one week. Hua et al. (2016) proved that insecticides reduced cercariae growth in frogs but not in a dose-dependent manner. Therefore, knowledge of pesticide pollution and the abundance of blood parasites in anurans is important because anurans are sensitive towards different environmental conditions. In view of the above, the present study was conducted to investigate the effect of water quality index and pesticide pollution on frog population in different locations of Malaysia and the parasite abundance in those populations. This study was carried to gain knowledge on the protozoa and haemoparasites infecting the anurans, which are important indicators of a healthy ecosystem with diverse amphibian populations, and to save amphibians from extinction.

\section{Materials and Methods}

Study areas: The research was carried out in three separate locations: Jeriau river and Fraser's hill golf course in the state of Pahang, and UKM Danau golf club in the state of Selangor (Fig. 1). The reference location, Jeriau river, is a recreational site surrounded by forest and has a fast-flowing water stream. UKM Danau golf club is in a lowland area while Fraser's hill golf course is located on a highland area; both have greenery areas and stagnant water suitable for anurans.

Sample collection for water quality index and metsulfuron methyl detection analyses: Water samples were collected for water quality index and metsulfuron methyl detection analysis from three stations at each location. In-situ water quality index analysis was carried out for measuring $\mathrm{pH}$ and dissolved oxygen (DO); ex-situ water quality index analysis involved measuring total suspended solids (TSS), biochemical oxygen demand (BOD), chemical oxygen demand (COD) and ammonia-nitrogen concentrations $\left(\mathrm{NH}_{3}-\mathrm{N}\right)$. Water samples were collected in glass bottles to run the analysis.

Collection of anurans: Anurans were randomly collected from three locations and were caught at night by hand and net. The captured frogs were placed in disposable plastic bags with few holes for air and were transferred to laboratory. To prevent frogs from killing each other, each frog was then placed in a separate aquarium with sufficient water to avoid dehydration of their skin. A total of 140 different anuran species were captured. Their species were identified according to the descriptions of Berry (1975). Samplings were performed in November and December 2017 and in February, March and April 2018. This study was approved by the Animal Ethics Committee of Universiti Kebangsaan Malaysia (UKMAEC: FST/2017/HANI/25-JAN./823-JAN.-2017JUNE-2017-AR-CAT2).

Water quality analyses: Six physico-chemical parameters were measured in this study and were divided into in-situ and ex-situ parameters. In-situ parameters such as $\mathrm{pH}$ and DO concentration are unstable parameters and were recorded in the field (APHA, 2018). The pH and DO in water sampling stations were measured with a YSI 556 handheld multi-parameter instrument (Yellow Springs Instrument, Ohio, USA). The ex-situ 

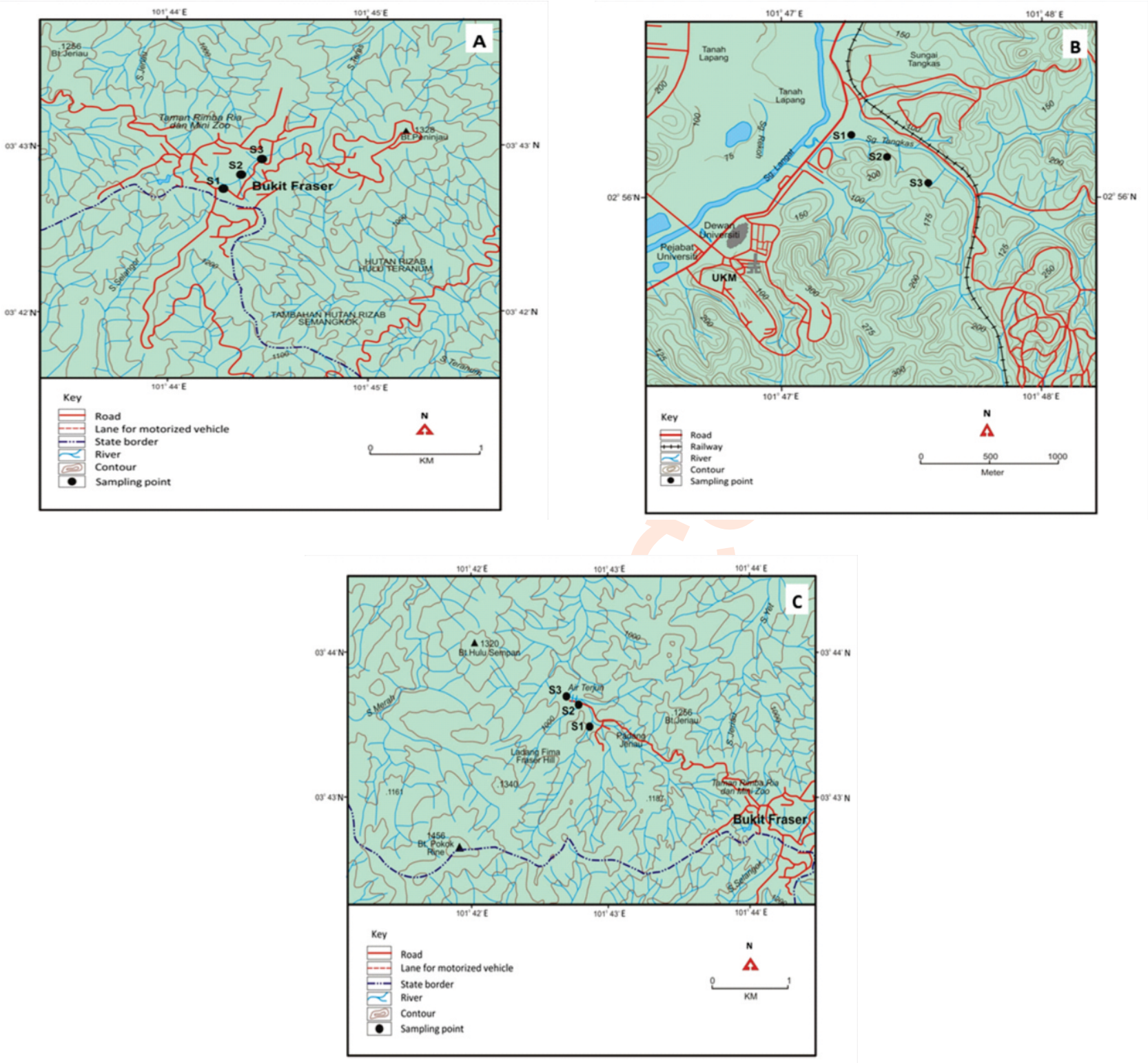

Fig. 1 : Topography maps of (A) Fraser's hill golf, (B) UKM Danau golf club and (C) Jeriau river.

analyses included $\mathrm{BOD}, \mathrm{COD}$, TSS and $\mathrm{NH}_{3}-\mathrm{N}$ testing. Ex-situ $\mathrm{BOD}$ testing was conducted using sampling water, which was kept in a dark glass bottle for 5 days at $18^{\circ} \mathrm{C}$ to avoid contact with sunlight, as it might affect the reaction of bacteria present in the water. The initial and final BOD values on the first and last days were measured with a YSI 5000 DO instrument (Yellow Springs Instrument, Ohio, USA). The BOD values were defined as the difference between the initial and final BOD values. The experiment was repeated three times. COD testing involved addition of COD low-range digestion reagent to water samples and was heated at $150^{\circ} \mathrm{C}$ in a Hach COD reactor Model 45600 (Hach Co., Colorado, USA) or $2 \mathrm{hr}$. The samples were allowed to cool before the absorbance was read. The colour change of water samples was measured with a Hach DR/2010 spectrophotometer (Hach Co., Colorado, USA) at $420 \mathrm{~nm}$ wavelength. TSS was measured with a Hach DR/2010 spectrophotometer. The water quality index of the samples was determined based on in-situ and ex-situ analyses; all six physicochemical parameters were used to calculate the water quality index. Water quality index was calculated based on the equation below, where si indicates the sub-index. The water quality parameter classification (Table 1) was based on the Guidelines of Department of Environment Malaysia (DOE, 2008).

Water quality index $=0.22(\mathrm{siDO})+0.19(\mathrm{siBOD})+0.16(\mathrm{siCOD})+$ $0.15\left(\mathrm{siNH}_{3}-\mathrm{N}\right)+0.16(\mathrm{siTSS})+0.12(\mathrm{sipH})$ 
Table 1: Six water quality parameters from National Water Quality Standards for Malaysia (NWQS)

\begin{tabular}{|c|c|c|c|c|c|}
\hline \multirow[t]{2}{*}{ Parameters } & \multirow[b]{2}{*}{ I } & \multicolumn{2}{|c|}{ Class } & \multirow[b]{2}{*}{ IV } & \multirow[b]{2}{*}{ V } \\
\hline & & II & III & & \\
\hline BOD & $<1$ & $1-3$ & $3-6$ & $6-12$ & $>12$ \\
\hline COD & $<10$ & $10-25$ & $25-50$ & $50-100$ & $>100$ \\
\hline DO & $>7$ & $5-7$ & $3-5$ & $1-3$ & $<1$ \\
\hline TSS & $<25$ & $25-50$ & $50-150$ & $150-300$ & $>300$ \\
\hline $\mathrm{NH}_{3} \mathrm{~N}$ & $<0.1$ & $0.1-0.3$ & $0.3-0.9$ & $0.9-2.7$ & $>2.7$ \\
\hline $\mathrm{pH}$ & $>7.0$ & $6.0-7.0$ & $5.0-6.0$ & $<5.0$ & - \\
\hline
\end{tabular}

Source: DOE, 2008. All values are in $\mathrm{mg}^{-1}$; except for $\mathrm{pH}$

Metsulfuron methyl extraction and identification: A total of 3 I of water samples were used for metsulfuron methyl extraction in high-performance liquid chromatography (HPLC). All reagents and solvents used in the study were HPLC-grade. Separations were performed on a ZORBAX Eclipse XDB-C18 column (Agilent Technologies, California, USA). The mobile phases used were methanol : acetonitrile : acetic acid, and phosphate buffers : acetic acid, with $\mathrm{pH}$ adjusted to 2.5. The column temperature was controlled at $40^{\circ} \mathrm{C}$. The targeted pesticide was detected at 200 $\mathrm{nm}$ wavelength. Each separation was performed in triplicate. Metsulfuron methyl was then extracted with a reverse-phase solid-phase extraction cartridge, and the analytes were eluted off the solid-phase extraction cartridge using methanol. The resulting elute was evaporated near to dryness, filtered and submitted for chemical identification (mass spectrometry analysis) and quantification.

Protozoa and haemoparasite screening: In the laboratory, the anurans were killed by pitching. Blood was obtained from the heart to prepare thin blood smears for screening blood parasites. Thin blood smears were prepared from one drop of blood spread on a dry glass slide, air-dried and fixed in absolute methanol for 3 min and stained with Giemsa for 30 min (Omonona and Ekpenko, 2011). The smears were screened under $\times 400$ magnification and ×1000 immersion oil objective under a light microscope for haemoparasite diagnosis, and images were captured with a Canon digital camera (Canon, Tokyo, Japan). Five organs, i. e., liver, stomach, intestine, rectum and kidney were extracted from the anurans. The organs were dissected from the body and prepared for histological examination using standard techniques. The tissues were paraffin-embedded, sectioned at $4 \mu \mathrm{m}$ thickness, stained with haematoxylin and eosin, and examined under $\times 400$ and $\times 1000$ magnification using a Nikon Eclipse E400 compound microscope (Nikon Corporation, Tokyo, Japan) for identifying the protozoa.

Statistical and biodiversity index analysis: All data were recorded and analysed with Graph Pad Prism statistical software. The significant difference $(p<0.05)$ between each water sample from each study location was determined by a two-way ANOVA.
The biodiversity index, i.e., Simpson's index was measured to determine the species richness, abundance and diversity of anurans in each study location, and was calculated by Paleontological Statistics (PAST) software.

\section{Results and Discussion}

In-situ physico-chemical analyses of water samples showed that Jeriau river had the highest DO value (91.1\%), followed by Fraser's hill golf course (69.8\%) and UKM Danau golf club (35.2\%) (Table 2). Two-way ANOVA using Tukey test showed that the $\mathrm{DO}$ values were significantly different $(p<0.05)$ between Jeriau river and Fraser's hill golf course, Jeriau river and UKM Danau golf club and between Fraser's hill golf course and UKM Danau golf club, respectively. In-situ physico-chemical analyses showed that the $\mathrm{pH}$ value for Jeriau river was 6.03 , while that for Fraser's hill golf course and UKM Danau golf club was 5.85 and 6.62 , respectively. Ex-situ analyses revealed that the BOD of Jeriau river was $3.9 \mathrm{mg} \mathrm{l}^{-1}$, while that of Fraser's hill golf course and UKM Danau golf club was $1.9 \mathrm{mg} \mathrm{l}^{-1}$ and $3.6 \mathrm{mg} \mathrm{l}^{-1}$, respectively. Jeriau river had the highest $\mathrm{BOD}$ level compared to Fraser's hill golf course and UKM Danau golf club. There was a significant difference $(p<0.05)$ between the BOD values of Jeriau river and both Fraser's hill golf course and UKM Danau golf club. Ex-situ analyses of COD for three locations showed that Jeriau river had $4.9 \mathrm{mg} \mathrm{I}^{-1} \mathrm{COD}$, while COD values in water samples of Fraser's hill golf course and UKM Danau golf club was $14.4 \mathrm{mg} \mathrm{l}^{-1}$ and $16.3 \mathrm{mg} \mathrm{l}^{-1}$, respectively. Jeriau river had the lowest COD compared to both Fraser's hill golf course and UKM Danau golf club, where both these locations had slightly different COD values. There was a significant difference $(p<0.05)$ between Jeriau river and Fraser's hill golf course and between Jeriau river and UKM Danau golf club. The ex-situ analysis showed that Jeriau river, Fraser's hill golf course and UKM Danau golf club had $4.1 \mathrm{mg} \mathrm{l}^{-1}, 8.9 \mathrm{mg} \mathrm{l}^{-1}$ and $8.5 \mathrm{mg} \mathrm{I}^{-1} \mathrm{TSS}$, respectively. Tukey test showed that the difference was significant $(p<0.05)$ between Jeriau river and Fraser's hill golf course and between Jeriau river and UKM Danau golf club. The $\mathrm{NH}_{3}-\mathrm{N}$ levels of Jeriau river, Fraser's hill golf course and UKM Danau golf club were $0.04 \mathrm{mg} \mathrm{I}$ ${ }^{1}, 0.8 \mathrm{mg} \mathrm{l}^{-1}$ and $2.8 \mathrm{mg} \mathrm{l}^{-1}$, respectively. UKM Danau golf club had 
Table 2 : Average values of physico-chemical parameters, water quality indices and MSM concentrations in Jeriau river, Fraser's hill golf, and UKM UKM Danau golf club

\begin{tabular}{|c|c|c|c|}
\hline \multirow[t]{2}{*}{ Parameters } & \multicolumn{3}{|c|}{ Locations } \\
\hline & Jeriau river & Fraser's hill golf & UKM Danau golf club \\
\hline $\mathrm{DO}(\%)$ & $91.1 \pm 3.5$ & $69.8 \pm 2.5$ & $35.2 \pm 8.2$ \\
\hline $\mathrm{pH}$ & 6.03 & 5.85 & 6.62 \\
\hline $\mathrm{BOD}\left(\mathrm{mgl}^{-1}\right)$ & $3.9 \pm 1.1$ & $1.9 \pm 0.2$ & $3.6 \pm 0.1$ \\
\hline $\operatorname{COD}\left(\mathrm{mg} \mathrm{l}^{-1}\right)$ & $4.9 \pm 1.2$ & $14.4 \pm 0.5$ & $16.3 \pm 1.5$ \\
\hline $\operatorname{TSS}\left(\mathrm{mgl}^{-1}\right)$ & $4.1 \pm 0.5$ & $8.9 \pm 1.3$ & $8.5 \pm 2.6$ \\
\hline $\mathrm{NH}_{3}-\mathrm{N}\left(\mathrm{mgl}^{-1}\right)$ & $0.04 \pm 0.01$ & $0.80 \pm 0.20$ & $2.80 \pm 0.60$ \\
\hline$\Sigma W Q$ & $93.0 \pm 3.0$ & $80.7 \pm 2.5$ & $60.7 \pm 2.1$ \\
\hline Class & 1 & $\|$ & III \\
\hline $\operatorname{MSM}\left(\mathrm{mg} \mathrm{I}^{-1}\right)$ & $0.0170 \pm 0.0010$ & $0.0095 \pm 0.0002$ & $0.0015 \pm 0.0002$ \\
\hline
\end{tabular}

Table 3 : Number and species of anurans captured from study sites

\begin{tabular}{|c|c|c|c|c|}
\hline Location & Families of anurans & Species of anurans & Number of anurans captured & Total anurans captured \\
\hline \multirow[t]{4}{*}{ Jeriau River } & Ranidae & $\begin{array}{l}\text { 1. Amolops larutensis } \\
\text { 2. Odorrana hosii }\end{array}$ & 57 & 75 \\
\hline & Dicroglossidae & 1. Limnonectes blythii & 15 & \\
\hline & Bufonidae & 1. Phyrnoidis asper & 2 & \\
\hline & Rhacophoridae & 1. Polypedates leucomystax & 1 & \\
\hline \multirow[t]{3}{*}{ Fraser's Hill Golf } & Ranidae & $\begin{array}{l}\text { 1. Amolops larutensis } \\
\text { 2. Hylarana luctuosa } \\
\text { 3. Odorrana hosii }\end{array}$ & 15 & 22 \\
\hline & Dicroglossidae & $\begin{array}{l}\text { 1. Fejervarya limnocharis } \\
\text { 2. Limnonectes blythii } \\
\text { 3. Limnonectes paramacrodon }\end{array}$ & 4 & \\
\hline & Rhacophoridae & 1. Polypedates leucomystax & 3 & \\
\hline \multirow[t]{6}{*}{ UKM Danau Golf Club } & Bufonidae & 1. Duttaphrynus melanostictus & 17 & 43 \\
\hline & Dicroglossidae & $\begin{array}{l}\text { 1. Fejervarya cancrivora } \\
\text { 2. Fejervarya limnocharis }\end{array}$ & 11 & \\
\hline & Ranidae & 1. Hylarana erythrea & 7 & \\
\hline & Microhylidae & 1. Kaloula pulchra & 6 & \\
\hline & Rhacophoridae & 1.Polypedates leucomystax & 2 & \\
\hline & & & & Total =140 \\
\hline
\end{tabular}

the highest $\mathrm{NH}_{3}-\mathrm{N}$ level compared to other two locations. Twoway ANOVA showed that there was a significant difference $(p<0.05)$ between the locations. Based on all recorded in-situ and ex-situ values, the water quality indices were measured and categorised into water quality index classes (Table 2). The water quality index of each location was calculated, and showed that Jeriau river had the highest water quality index value, i.e. 93, which belonged to Class I. This shows that the quality of Jeriau river was good as compared to that of Fraser's hill golf course (80.7) and UKM Danau golf club (60.7), which belonged to Class II and III, respectively. The water quality index of these three locations has been studied previously (Abdullah et al., 2015; Samsudin et al., 2012). Compared to that study, the average water quality index values in the present study were different, especially for Jeriau river, as previously reported water quality index value was 89.3 (Class II), however, in the present study, the water quality index value was 93.0 (Class I), suggesting that the water quality of Jeriau river was cleaner and suitable for animals. However, the water quality index values of Fraser's hill golf course and UKM Danau golf club did not change from the previous reported values and remained in the same class.

Metsulfuron methyl concentrations were $0.017 \mathrm{mg} \mathrm{I}^{-1}$ in Jeriau river was $0.017 \mathrm{mg} \mathrm{l}^{-1}, 0.0095 \mathrm{mg} \mathrm{l}^{-1}$ in Fraser's hill golf course and $0.0015 \mathrm{mg} \mathrm{l}^{-1}$ in UKM Danau golf club (Table 2), indicating that Jeriau river had the highest metsulfuron methyl concentration. The maximum amount of metsulfuron methyl stated by the National Health and Medical Research Council (NHMRC) Australian Drinking Water Guidelines was $0.04 \mathrm{mg} \mathrm{I}^{-1}$ (FSANZ, 2011). Thus, metsulfuron methyl levels at all locations 
Table 4 : Prevalence of protozoa and haemoparasites according to study locations

\begin{tabular}{lllll}
\hline Locations & $\begin{array}{l}\text { Prevalence of } \\
\text { protozoa (\%) }\end{array}$ & Identified protozoa & $\begin{array}{l}\text { Prevalence of } \\
\text { haemoparasites (\%) }\end{array}$ & $\begin{array}{l}\text { Identified } \\
\text { haemoparasites }\end{array}$ \\
\hline Jeriau river & 22.67 & $\begin{array}{l}\text { 1. Opalinata } \\
\text { 2. Ciliophora (Nyctotherus cordiformis) }\end{array}$ & 53.19 & $\begin{array}{l}\text { 1. Aegyptianella } \\
\text { 2. Lankesterella } \\
\text { 3. Haemogregarine } \\
\end{array}$ \\
& & & & 4. Trypanosoma \\
Fraser's hill golf & 54.55 & 1. Opalinata & & 1. Lankesterella \\
& & 2. Ciliophora (Nyctotherus cordiformis) & 2. Haemogregarine \\
UKM Danau golf club & 30.23 & 1. Opalinata & 41.00 & 1. Microfilaria \\
& & & & 2. Aegyptianella \\
& & & & 3. Lankesterella \\
& & & 4. Haemogregarine \\
\end{tabular}

were within the permissible limit. Even though the metsulfuron methyl concentration in this study was very low, sub-lethal concentrations of metsulfuron methyl $\left(5.8 \mu \mathrm{gl}^{-1}\right)$ affected the acetylcholinesterase activity in brain and tissues of teleost fish (Leporinus obtusidens). A previous study suggested that glyphosate-based herbicide can inhibit acetylcholinesterase levels in tadpoles (Lajmanovich et al., 2011). Acetylcholinesterase is required for deactivating acetylcholine activity at nerve endings, which is crucial for neuromuscular systems, and is a common biomarker in neurotoxic studies (Ballinger et al., 2005; Kroth et al., 2018). Besides, the hydrophilic properties, metsulfuron methyl also affects the development of anurans at tadpole stage.

Total 140 anurans captured comprised 13 different species (Table 3): Amolops larutensis, Hylarana erythraea, $\mathrm{H}$. luctuosa, Odorrana hosii, Fejervarya limnocharis, F. cancrivora, Limnonectes blythii, L. paramacrodon, Duttaphrynus melanostictus, Phrynoidis aspera, Kaloula pulchra, Polypedates leucomystax and Rhacophorus prominanus. The biodiversity index calculation showed that the anurans were more evenly distributed in UKM Danau golf club compared to other two locations, as shown by higher Simpson's index value (0.76), followed by Fraser's hill golf course (0.67) and Jeriau river (0.55), indicating diverse anuran populations in three locations. About 42 of 140 anurans were infected by protozoa. The level of infection was highest in anurans from Fraser's hill golf course (54.55\%), followed by UKM Danau golf club (30.23\%) and Jeriau river $(22.67 \%)$ (Table 4). Protozoa were found in the intestines and rectum. No protozoa were found in liver, stomach, kidney. The protozoa comprised Phyla Opalinata and Ciliophora. In all study locations, the prevalence of Opalinata (22.14\%) was higher than Ciliophora (10.71\%). The prevalence of protozoa in the rectum $(28.57 \%)$ was higher than in the intestine (10.71\%). No Ciliophora were found in anurans from UKM Danau golf club, while Opalinata were found in anurans from all three locations. Opalinata was most abundant in anurans from UKM Danau golf club while Ciliophora was most abundant in anurans from Jeriau river. Microscopic study showed that the Ciliophoran protozoa were $N$. cordiformis, as the macronucleus and cytopharynx could be clearly seen. This finding corroborates with the results of Muhammad et al. (2013), who examined four species of wild anurans from a local zoo in Malaysia. They reported that species from Phylum Opalinata were most commonly found in the intestine and rectum, and also N. cordiformis was also found in the anurans blood. In the present study, N. cordiformis co-existed with species of Phyla Opalinata, which is similar to the study of Muhammad et al. (2013). On the other hand, McAllister et al. (2013) also found these protozoa in anuran rectum. These two Phyla (Opalinata and Ciliophora) are known as cosmopolitan protozoa. Rahman et al. (2008) added that these ciliated protozoa are common in the digestive tract of anurans. Ponyton and Whitaker (2001) observed that these two protozoa have a commensal relationship with their hosts. Even though they were found in high numbers, they did not cause any damage to the host (Al-Khamesi et al., 2018; Jimenez and Sommer, 2017; Ponyton and Whitaker, 2001).

From 140 anurans captured, only 99 blood smears were prepared. Of these, 44 blood smears were infected with at least one group of haemoparasites. About $44.44 \%$ of anurans were infected with haemoparasites. Five groups of haemoparasites, namely Trypanosoma, Haemogregarina, Aegyptianella, Lankesterella and microfilaria were found (Fig. 2). Trypanosoma was identified by observing the kinetoplast and undulating membrane. Some trypanosomes have a conspicuous kinetoplast, while others have a clear undulating membrane. The highest infection of haemoparasites was caused by Trypanosoma (34.34\%), followed by Haemogregarina (19.19\%), Aegyptianella (8.08\%), Lankesterella (4.04\%) and Microfilaria $(1.01 \%)$. Haemoparasite infection was highest in the anurans captured from Jeriau river, with a prevalence of $53.19 \%$, followed by frogs collected from UKM Danau golf club (41.67\%) and Fraser's hill golf course (25\%) (Table 4). UKM Danau golf club anurans had the most haemoparasite groups compared to Jeriau river and Fraser's hill golf course. The haemoparasites present in 

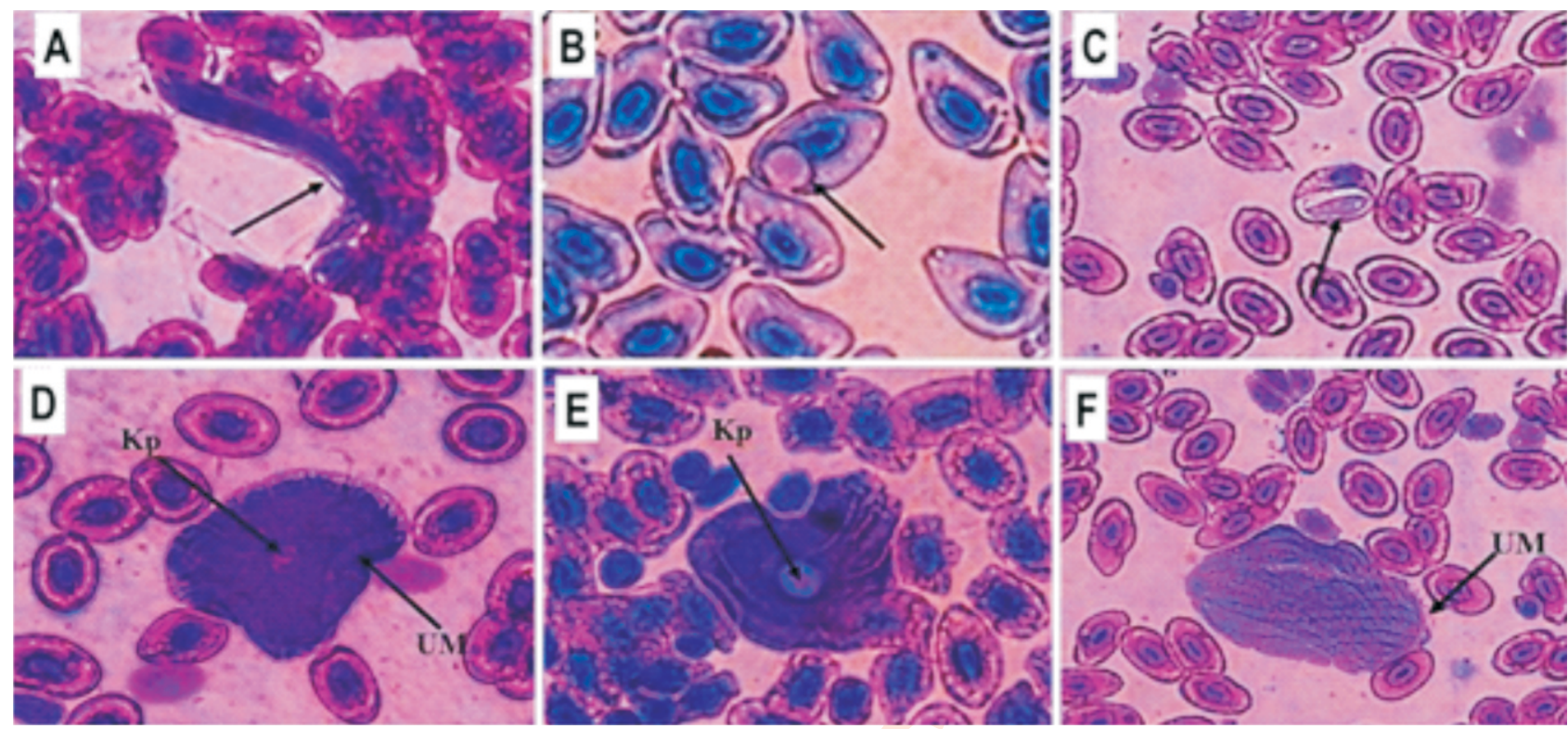

Fig. 2 : Haemoparasites identified in anurans from three study locations using Giemsa staining and viewed under light microscope at $\mathrm{x} 1000$ magnification; (A) Microfilaria, (B) Aegyptianella sp., (C) Lankesterella sp., and (D, E and F) Trypanosoma sp. with kinetoplast (Kp) and undulating membrane (UM). Arrows showed the presence of parasites.

UKM Danau golf club anurans consisted of Trypanosoma, Haemogregarina, Lankesterella, Aegyptianella and microfilaria. Jeriau river anurans had four groups of haemoparasites: Trypanosoma, Haemogregarina, Lankesterella and Aegyptianella, while Fraser's hill golf course anurans had only two groups of haemoparasites: Haemogregarina and Lankesterella. Trypanosoma was the most abundant haemoparasite group in the Jeriau river and UKM Danau golf club anurans, followed by Haemogregarina in Jeriau river and UKM Danau golf club anurans. Haemogregarina was most abundant in Fraser's hill golf course anurans; Aegyptianella was present only in Jeriau river and UKM Danau golf club anurans. Overall, Trypanosoma was highly prevalent. A similar result was reported by Sailasuta et al. (2011) in their study conducted in Thailand. A previous study by Muhammad et al. (2013) conducted in Malaysia found only two groups of parasites: Trypanosoma and Lankesterella, while another study also conducted in Malaysia but in other locations reported presence of five groups of haemoparasites (Rahman and Shakinah, 2015). The findings on haemoparasites by Rahman and Shakinah (2015) are similar to that of our study. In the present study, a double-nucleated red blood cells in the blood smears was observed, which might due to the effect and action of parasites on the blood cells (Aisien et al., 2015; Omonona and Ekpenko, 2011).

In this study, Trypanosoma were found in H. erythraea, $F$. cancrivora, F. limnocharis, L. blythii, O. hosii, Amolops larutensis and $D$. melanostictus. The presence of Trypanosoma in 7 of 15 species in the present study differs from the findings of
Muhammad et al. (2013), who found that Trypanosoma was restricted to a single host ( $H$. erythraea) and $D$. melanostictus was not infected by Trypanosoma. Trypanosoma infecting humans are pathogenic, and differ from Trypanosoma species present in anurans, which are mostly non-pathogenic (Spodareva et al., 2018). The present study found that Lankesterella was found only in $A$. larutensis but none were found in $H$. erythraea, which is contrary to the findings of Muhammad et al. (2013), who found Lankesterella only in $H$. erythraea. Muhammad et al. (2013) concluded that Lankesterella is host-specific to $H$. erythraea, but Lankesterella might also be host-specific to $A$. larutensis, as Lankesterella was only found in A. larutensis in this study. $H$. erythraea was found only in UKM Danau golf club anurans, while A. larutensis was found only in Jeriau river and Fraser's hill golf course anurans. It is possible we did not find Lankesterella in $H$. erythraea because it does not exist at UKM Danau golf club. Muhammad et al. (2013) theorised that leeches might be the vector that transmits both Lankesterella and Trypanosoma in aquatic frogs like $H$. erythraea. They also stated that as $H$. erythraea spends most of its time in water, it has higher possibility of being infected through blood-sucking leeches, this might be the reason for high prevalence of Trypanosoma infection in $A$. larutensis and was the only species infected by Lankesterella. Mann (2013) reported that leech Placobdella marginata is the vector responsible for disseminating Lankesterella to anurans through blood-sucking activity. This is supported by Du Preez (2015), who suggested that the higher prevalence of haemoparasites in two species of semi-terrestrial frogs is due to their preference for habitats close to water. Other than that, 
Netherlands et al. (2015) added that the number of possible vectors (mosquitoes and leeches) are high in habitats close to water, as the abundance of possible vectors is related to water. This might explain why Jeriau river anurans had the highest prevalence of haemoparasites, followed by UKM Danau golf club and Fraser's hill golf course anurans. According to Netherlands et al. (2015) the anurans' diet might be one of the factor affecting the presence of haemoparasites.

In conclusion, water quality, pollution, and chemical contaminants did not affect the diversity of anurans and the prevalence of protozoa and blood parasites in these locations. This is proven by the fact that UKM Danau golf club, with the lowest water quality index, i. e. Class III, had the most diverse anuran species and the highest prevalence of haemoparasites. Thus, there is insufficient evidence to show any relationship between environmental parameters and parasite abundance. The findings of the present study contribute to our understanding of the factors of improving and preserving the ecosystem and survival of the amphibians as well as preventing contaminants that could destroy the pleasant habitat of the animals.

\section{Acknowledgments}

This research was supported by research grants from the Ministry of Science, Technology, and Innovation (06-01-02SF1367) and the Ministry of Education (FRGS/1/2019/STG03/ UKM/03/2). We also wish to thank the Department of Earth Sciences and Environment, Faculty of Science and Technology, Universiti Kebangsaan Malaysia, for facilitating this research, which was carried out in their respective laboratories.

\section{Add-on Information}

Authors' contribution : H.K. Agustar: writing-original draft preparation, methodology, writing-review and editing, supervision; K.M. Jansar: supervision, investigation; A.H. Ali: writing-review and editing; N.F.A. Ghani: methodology, investigation.

Research content : The research content is original and has not been published elsewhere.

Ethical approval : This study was approved by the animal ethics committee of Universiti Kebangsaan Malaysia (UKMAEC: FST/ 2017/HANI/25-JAN./823-JAN.-2017-JUNE-2017-AR-CAT2).

Conflict of interest: The authors declare that there is no conflict of interest.

\section{Data from other sources : Not applicable}

Consent to publish : All authors have read and agreed to publish the paper in Journal of Environmental Biology.

\section{References}

Abdullah, M.P., W.M.A.W.M. Khalik and M.I. Idris: Water quality of the Raub-Fraser's hill corridor. Proceeding SESKORFRA, 2015, 104108 (2015).

Aisien, M.S.O., P.O. Aigbirior, E. Ovwah and O. Edo-Taiwo: Blood parasites of some anurans from southern Nigeria. Trop. Biomed., $32,598-607$ (2015).

Alford, R.A. and S.J. Richards: Global amphibian declines: A problem in applied ecology. Annu. Rev. Ecol. Evol. Syst., 30, 133-165 (1999).

Al-Khamesi, M.B., I.S. Salman, S.A. Abid and S.M. Ibrahim: Study prevalence and effect of internal parasites and histopathological changes on common frogs at Baghdad city. Iraqi J. Agric. Sci., 49, 445-451 (2018).

APHA: Standard methods for the examination of water and waste water, 21st Edition, American Public Health Association, Washington (2005).

Ballinger, C.A., R. Cueto, G. Squadrito, J.F. Coffin, L.W. Velsor, W.A. Pryor and E.M. Postlethwait: Antioxidant-mediated augmentation of ozone-induced membrane oxidation. Free Radic. Biol. Med., 38, 515-526 (2005).

Bernardo-Cravo, A.P., D.S. Schmeller, A. Chatzinotas, V.T. Vredenburg and A. Loyau: Environmental factors and host microbiomes shape host-pathogen dynamics. Trends Parasitol., 36, 616-633 (2020).

Berry, P.Y.: The amphibian fauna of Peninsular Malaysia. Tropical Press, Kuala Lumpur, Malaysia (1975).

Blaustein, A.R., J. Urbina, P.W. Snyder, E. Reynolds, T. Dang, J.T. Hoverman, B. Han, D.H. Olson, C. Searle and N.M. Hambalek: Effects of emerging infectious diseases on amphibians: Areview of experimental studies. Diversity, 10, 1-49 (2018).

Bradford, D.F., R.A. Knapp, D.W. Sparling, M.S. Nash, K.A. Stanley, N.G. Tallent-Halsell, L.L. Mcconnell and S.M. Simonich: Pesticide distributions and population declines of California, USA, alpine frogs, Rana muscosa and Rana sierra. Environ. Toxicol. Chem., 30, 682-691 (2011).

Brown, S.R., R.W. Flynn and J.T. Hoverman: Perfluoroalkyl substances increase susceptibility of northern leopard frog tadpoles to trematode infection. Environ. Toxicol. Chem., 40, 689-694 (2021).

Bruhl, C.A., T. Schmidt, S. Pieper and A. Alscher: Terrestrial pesticide exposure of amphibians: An underestimated cause of global decline?. Sci. Rep., 3, 1135 (2013).

Ceballos, G., P.R. Ehrlich and R. Dirzo: Biological annihilation via the ongoing sixth mass extinction signaled by vertebrate population losses and declines. PNAS, 114, E6089-E6096 (2017).

Collins, J.P. and A. Storfer: Global amphibian declines: Sorting the hypotheses. Divers. Distrib., 9, 89-98 (2003).

DOE: Malaysia Environmental Quality Report 2007. Department of Environment, Ministry of Natural Resources and Environment, Malaysia (2008).

Du Preez, L.: A complete guide to the frogs of southern Africa. Penguin Random House, South Africa (2015).

FSANZ: Chemical Guidelines/Standards for Drinking Water (at Approval) - Application A1043. Food Standards Australia New Zealand. https://www.foodstandards.gov.au/code/applications/ documents/A1043_SD2.pdf(2011).

Hayes, T.B., P. Falso, S. Gallipeau and M. Stice: The cause of global amphibian declines: A developmental endocrinologist's perspective. J. Exp. Biol., 213, 921-933 (2010).

Hua, J., N. Buss, J. Kim, S.A. Orlofske and J.T. Hoverman: Population- 
specific toxicity of six insecticides to the trematode Echinoparyphium sp. Parasitology, 143, 542-550 (2016).

Hua, J., V.P. Wuerthner, D.K. Jones, B. Mattes, R.D. Cothran, R.A. Relyea and J.T. Hoverman: Evolved pesticide tolerance influences susceptibility to parasites in amphibians. Evol. Appl., 10, 802-812 (2017).

Jimenez, R.R. and S. Sommer: The amphibian microbiome: Natural range of variation, pathogenic dysbiosis, and role in conservation. Biodivers. Conserv., 26, 763-786 (2017).

Kiesecker, J.M.: Synergism between trematode infection and pesticide exposure: A link to amphibian limb deformities in nature? PNAS, 99, 9900-9904 (2002).

Kroth, A., V. Mackedanz, C. Matté, A.T.D.S. Wyse, M.F.M. Ribeiro and W.A. Partata: Effect of sciatic nerve transection on acetylcholinesterase activity in spinal cord and skeletal muscles of the bullfrog Lithobates catesbeianus. Braz. J. Biol. Sci., 78, 217$223(2018)$

Lajmanovich, R.C., A.M. Attademo, P.M. Peltzer, C.M. Junges and M.C. Cabagna: Toxicity of four herbicide formulations with glyphosate on Rhinella arenarum (Anura: Bufonidae) tadpoles: B-esterases and glutathione S-transferase inhibitors. Arch. Environ. Con. Tox., 60, 681-689 (2011)

Mann, K.H.: Leeches (Hirudinea): Their structure, physiology, ecology and embryology (Vol. 11). Elsevier (2013).

McAllister, C., C.R. Bursey, M.B. Connior and S.E. Trauth: Symbiotic protozoa and helminth parasites of the Cajun Chorus Frog, Pseudacris fouqettei (Anura: Hylidae), from Southern Arkansas and Northeastern Texas, U.S.A. Comp. Parasitol., 80, 96-104 (2013).

Muhammad, K.N., M.M. Badrul, N. Mohamad and A.H. Zainal-Abidin: Protozoan parasites of four species of wild anurans from a local zoo in Malaysia. Trop. Biomed., 30, 615-620 (2013).

Netherlands, E.C., C.A. Cook, D.J.D. Kruger, L.H. Du Preez and N.J. Smit: Biodiversity of frog haemoparasites from sub-tropical northern KwaZulu-Natal, South Africa. Int. J. Parasitol. Par., 4, 133-141 (2015).
Omonona, A.O. and V. Ekpenko: Haematology and prevalence of blood parasites of the common frog (Rana temporaria) in the tropical environment. J. Vet. Med. Anim. Hlth., 3, 14-20 (2011).

Ponyton, S.L. and B.R. Whitaker: Protozoa and metazoan infecting amphibians. In: Amphibian Medicine and Captive Husbandry (Eds.: K.M. Wright and B.R. Whitaker). Krieger Publishing Company, Florida, USA(2001).

Pretto, A., V.L. Loro, C. Menezes, B.S. Moraes, G.B. Reimche, R. Zanella and L.A. de Ávila: Commercial formulation containing quinclorac and metsulfuron methyl herbicides inhibit acetylcholinesterase and induce biochemical alterations in tissues of Leporinus obtusidens. Ecotox. Environ. Safe., 74, 336-341 (2011).

Rahman, W.A. and Z. Shakinah: Influence of some environmental parameters on some frog populations and their parasitic fauna. $J$. Veterinar. Sci. Technol., 6, 3-10, (2015).

Rahman, W.A., A. Tan and I. Sufina: On the parasitic fauna of two species of anurans collected from Sungai Pinang, Penang Island, Malaysia. Trop. Biomed., 25, 160-165 (2008).

Rohr, J.R., T.R. Raffel, S.K. Sessions and P. J. Hudson: Understanding the net effects of pesticides on amphibian trematode infections. Ecol. Appl., 18, 1743-1753 (2008).

Sailasuta, A., J. Satetasit and M. Chutmongkonkul: Pathological study of blood parasites in rice field frogs, Hoplobatrachus rugulosus (Wiegmann, 1834). Vet. Med. Int., 2011, 1-5 (2011).

Samsudin, M.W., L. Din, Z. Zakaria, J. Latip, T. Lihan, A.A. Jemain and F. Samsudin: Measuring air quality using lichen mapping at Universiti Kebangsaan Malaysia (UKM) campus. Procedia Soc. Behav. Sci., 59, 635-643 (2012).

Sparling, D.W. and G.M. Fellers: Toxicity of two insecticides to California, USA, anurans and its relevance to declining amphibian populations. Environ. Toxicol. Chem., 28, 1696-1703 (2009).

Spodareva, V.V., A. Grybchuk-leremenko, A. Losev, J. Votýpka, J. Lukeš, V. Yurchenko and A.Y. Kostygov: Diversity and evolution of anuran trypanosomes: Insights from the study of European species. Parasites Vectors, 11, 1-12(2018). 